\title{
Language Teacher Education: Identities Under Construction
}

\author{
Selma Maria Abdalla Dias Barbosa
}

Universidade Federal do Tocantins-UFT

\begin{abstract}
This ethnographic and longitudinal study is aimed at investigating, analyzing and understanding the complex process of professional, social and cultural identity (re)construction of pre-service teachers in a Teacher Education Course at a Federal University in the extreme north of Brazil. The pre-service teacher's narratives were investigated through a qualitative approach. The narratives were collected from these students-teachers during the four semesters of their supervised internship class in their undergraduate course, as well as the interactions they posted in the Community of Practice - CdP - and discussed in thematic sessions accomplished during the process of investigation.
\end{abstract}

Keywords: Identities. Pre-service Teachers. Community of Practice.

\section{Introduction}

In our rush to reform education, we have forgotten a simple truth: reform will never be achieved by renewing appropriations, restructuring schools, rewriting curricula, and revising text if we continue to demean and dishearten the human resource called the teacher on whom so much depends (PALMER, 1998, p. 3, apud ALSUP, 2006, p.20).

This study which is about the (re)construction of professional identities of teachers in their initial formation started with uneasiness generated throughout approximately, eighteen years of experience with the bachelor's degree and six years of English teaching in elementary public school, and this always made me to ask: How to be a teacher in public schools without omitting the personal self? How to be a teacher in public schools without leaving besides your personal essence or your personal style, passions, beliefs, and ideologies? These questions, in turn, emerged having as a triggering element the fact that the most I experienced in elementary teaching was the following guidance from my partners and superiors, which in teacher training courses, still persists in the voice of my students: "You have to frame in the system or the system swallows you!", and also: "You have to be adjusted to the school system, it is not good to row against the tide!" and also: "Through the years, or you are adjusted to the function of the school or you give up at the beginning of the profession!.

Reflecting about how to work in the initial formation of language teachers to help them how to deal with these and other professional impasses and demands, I found myself with the already existent theories about teacher identities, because for me it is obvious the pertinence of this professional to know himself/herself better, understand the other, and know how to make interact his/her self-personal with his/her self-professional. This self-professional is, according to studies in the area of social studies, much more complex that the simple mixture or combination of the two essences- personal and professional- and therefore, it is worth to highlighting that the interaction between these two instances is very important, because if it was not like that, the identity of the professor would fail, which could lead of a simple omission of one of the two pillars in the constitution of professional education.

The integration of aspects of the self-personal with expectations and demands of the self-professional is much more complex that a simple union of the two parts (ALSUP, 2006), or even more than mere juxtaposition of I versus the OTHER for the constitution of a professional identity more autonomous, reflexive, conscious and politically active. Alsup (2006) points out the synergy of I versus the Other, self-personal versus self-professional involves to bring these binaries parts together, to mix and unit them providing a collision among the personal ideologies and the professional expectations experienced in the pedagogical practices, that exist in public schools bringing to surface a third renewed identity face. According to the author, for achieving this it is necessary that we provide activities and instances that instigate our students' formation to engage in Borderland Discourse 2, which in her words it is characterized like this: 
Discourse in which there is evidence of integration or negotiation of personal and professional selves. It is at the discourse borderlands and by associations at the borders of various subjectivities or senses of self, that preservice teachers can discover how to move from being students to being teachers, and can learn how to embody a workable professional teacher identity without sacrificing personal priorities and passions. (ALSUP, 2006, p. xiii- xiv).

It is perceived that as well the nomenclature as the definition of the expression borderland discourse, according to the excerpt, are not free from risks, such as simplifying too much or to reduce an ambiguous and complex process as the transformation and (re)construction of identities is. That is, a passage of identity of student-intern to become a language professor. In the words' author:

The problem with naming something like a form of discourse that facilitates identity formation is that readers may think it is stable, always similar, and easily identifiable across time and space (ALSUP, 2006, p. 5).

On contrary, that definition does not embrace all the scope and the complexity of the process as well. It is a challenging definition of every kind of discourse and not the intuitive to make easy the study in this process. Alsup created that nomenclature, which in front of her justifications; I believe it is pertinent and relevant to advance in studies about identity construction. It is important to point out that in the same way than the author caught up, it also occurred in this study of identity construction many times, during the path of her study of borderland discourse discussing and exploring more the power of the cognitive, emotional and psychological aspects instead of linguistics ones properly mentioned in the discourse. Without detracting the linguistic values and the strategy of exploring a field so obscure and unstable such the subjectivities of human being and his/her thinking, I chose to emphasize the sociolinguistic and emotional aspects of the discourse.

Despite the ambiguity registered in the own definition of the borderland discourse that sometimes refers to something stable, something fluid, moving from one to another position; I would like to make it clear to the lector that it kind of discourse is "complex, rich and depends on the social, cultural and historical context in which it is. (ALSUP, 2006, p.5). In other words, the transformative discourse of identities reflects in a more holistic vision of the identity of the preservice teacher, that is to say, his/her intellectual, corporal and emotional aspects in the regular (re)construction and integration of the self-personal to the self-professional, or still: the interaction among the different personal and professional subjectivities and thus, a eventual integration of those multiple identities facets or the subjectivities of the I.

In consonance with the points of the author, it has vital relevance that teachers engage on that kind of borderland discourse in which, despite the relationship, is sometimes tense and conflictive among those subjectivities. They can develop a professional identity making it richer, reflexive and active in the creation of an own and coherent pedagogy perspective according to its context or educational community. Taking into consideration some studies of the Training Education Area (ROGERS \& BABINSKI, 2002; GRANT \& ZEICHNER, 1981; ALSUP, 2006), we can point out that there is a baggage of information about the confronted problems by teachers at the beginning of their career and thus, it is still a challenge during that period of experience with teaching, because as Rogers \& Babinsky (2002, p. 2) say: "despite all the investigation and all the books, and articles written about the difficulties confronted by preservice teachers, the first year of teaching continues being a moment extremely difficult for the majority of them".

Besides that, according to some investigations (GORDON, 1991; HULING-AUSTIN, et al. 1989), $50 \%$ of the course of novice teachers does not last more than five years for making the situation even more worrying. Many teachers that choose to continue in the profession teach in an inconsistent and contradictory way with the pedagogical conceptions, beliefs, objectives and expectations they had, when they initiated a degree course or the ones that they created during their formation. So, many of them, in order to survive inside a system that generally exists in schools, remain in their classroom surrendered to the traditional system of teaching and such fixed and stereotyped identification of professor that is culturally disseminated in the social environment - emphasized, so contested in the last decades.

In front of those challenges found by the preservice teachers, it makes relevant the study of professional identities of those individuals, whose career demands much more of a professional than what was believed in earlier times, when it was thought that any person could teach just for desiring or vocation. Today, however, it is already observed how complex is the teaching and learning language system and the professor training (VIEIRA-ABRAHÃO, 1992, 1996, 2004; ALMEIDA FILHO, 2002 GIL, 2005; TELLES, 2002, 2009, and others).

To believe in the relevance of investigations that try through interdisciplinary dialogues, to clear the clashes and discursive games present in language classroom, outlining the professional, social and cultural identities; I have as a guiding thesis 
of this investigation the following: when approaching discussions about identity and emotional aspects at the university, we will contribute to the more autonomous and critical construction of identities from the agents involved in this initial formation process. Among those actors are the people that act in the disciplines of supervised internship of the degree courses, namely: trainer-teacher, preservice teacher, regent-teacher of the field-school, students of the field-school and pedagogical team, and some others.

It is not my objective just to point out punctual experiences of identity development of preservice teachers, but also to explore and explain how the (re)construction of identities occurs inside and outside the university, for example in practices communities. Keeping this in mind, I discuss in this article, the (re)construction of identities of teachers in initial formation, both in the presence context and the virtual one. For that, we divide the text in four different moments. At the first, I discuss the term identity and its theoretical conceptions and re-significations; in the second one, I analyze some excerpts that connote the identity of preservice teacher and subsequently, in the third, I analyze and discuss also other excerpts related to the identity of language teacher participants to, in fourth, bring some final considerations.

\section{Identity and Its Unfoldings}

In a word, multiple theoretical approaches are absolutely essential if we are not to lose sight of real world complexity of our subject (VARGHESE, MORGAN, JOHNSTON, JOHNSON, 2005, p. 40)

In the last twenty years, the investigations in the fields of Anthropology, Sociolinguistics and socio-cultural theories have influenced the investigation related to teaching and teacher training considerably (NORTON, 2000). We can find them in Applied Linguistics and more specifically in the initial formation of teachers (VIEIRA-ABRAHÃO, 2010, 2006; VIEIRAABRAHÃO e GIL, 2008; GIMENEZ, 2005; OLIVEIRA e PAIVA, 2005, 2004; COLLINS, 2004; CELANI, 2004, 2003; DUTRA, 2003; COLLINS e CELANI, 2003; CASTRO, 2001), theories that can make us reflecting, questioning and looking at the fertile land of identities through various perspectives. Or still, they can conduct us to several notions that involve the subjective and complex self-human sense in its transformer and transformative essence of the discourse as an inseparable instrument of that interaction of $I$ and the other, and the constant negotiation of identities at the infinitive forms of relations and social actions putting on all those questions in the center of attentions of studies on several areas, mainly the ones that delight with the magic of language and education.

If we keep distant from this tendency, we believe that those studies about professional (re)construction of identities approached in this work will contribute in actual and future ones to a better understanding of what means to be a teacher of foreign and mother languages; how to work in a efficient way in teaching learning languages, as well as in the training of future languages professors, in a context in which the subject on his totality odd is emerging from this process, that is much more than a simple addition of quantitative and evaluative results in its acquisition/learning or fluent in the target language.

According to Varghese et al. (2005), in recent years have increased considerably the number of investigations in Europe and USA that approach the teacher identity in the field of Applied Linguistics, which can be tested by the full bibliography already available (CLARKE, 2008; WENGER, 2008; ALSUP, 2006; MORGAN, 2004; PAVLENKO, 2003; JOHSTON, 2003, 1999; VARGHESE, 2000; DUFF \& UCHIDA, 1997). Also, something similar can be observed here in Brazil, what is evident when we notice the increasing number of studies about teachers' identity of foreign and mother languages in the country (FIGUEREDO, 2007; CORACINI \& GRIGOLETTO, 2006; SIGNORINI, 2006; MOITA LOPES, 2006, 2003; CORACINE, 2003; RAJAGOPALAN, 2003; BARBOSA, 2011).

Varghese et al. (2005) in their recent investigations concluded that a professor has a relevant participation in language classroom practices and consequently it became the focus of attention of researches. Also, they added that the researches related to beliefs, knowledge, attitudes, emotions, philosophy and some other factors, led us to conclude that all these aspects of self-professor cannot be analyzed separately at their singularities. On contrary, all of them are joined to form the identities of the teacher when performing in the classroom. Moreover, we believe that "this line of thinking, then, sees teacher identity as a crucial component in determining how language teaching is played out" and learned (VARGHESE et al., p. 22).

Besides, the authors point out that the investigations related to the socio-cultural and sociopolitical aspects also revealed the importance of the identity of the language teacher, because it is already a consensus in literature and not the neutrality pervades the role of the teacher, both in the classroom and in the broad context in which they are situated. According to the authors, those two lines of research are inside Applied Linguistics, the former encompasses the cognitive and affective 
aspects of a foreign language teacher; and the second one relates socio-cultural and sociopolitical aspects of a foreign language teacher. Those just led a scientific bias, whose orientation is inclined in the following sense: to understand the complex process of language teaching and learning, "Firstly, we need to comprehend the professor" (VARGHESE et al., 2005 , p. 22), that is to say, that we need to have a clear sense of who they are and in which cultural, social and professional context they are positioned or can be positioned by others at the interactional moment.

We agreed with the asseveration of the authors in which all the changes, consequently, provided relevant significations to the identity term in our post-structural times. One essential component of that change point out that the identity cannot be more understood as a something fixed, stable, unitary and coherent; but instead, it is a multiple transitory, transformational and transformative in conflict in its essence and capacity of management of human being in his identity formation -agency in identity formation-, bringing to dance an I as an intentional and administrator being of his identities. Another aspect is related to the fact that the identity cannot be analyzed in a isolated way from a social and historical context and for that reason, emerged an important component that is the relationship between the identity or the identities assumed by the individual, which he/she declares to posses -claimed identity- and the identity imposed by the others -assigned identitythat means, identities that the other affirms or recognizes in the individual.

A third component would be the interrupted verification of identities constructed and (re)constructed in a continuous process of negotiation of meaning through the discourse and language. We would add, still in this topic, the social aspect as an important tool of negotiation of identities. For example, the responsible action by the (re)construction of identities in communities of virtual or presence practices, which will be discuss more in detail. It is important to mention that Wenger (2008) introduces identity and social practices as parts of the same process, which means, our experiences of identities like a form of being in the world. Moreover, he made us know that a language/discourse is not everything in the construction of identities.

These visions and conceptual perspectives of identity are the ones that we will assume in this study and for achieving our goal; we will take as a potential instrument to comprehend these experiences of the participants, their emotions and identities, their narratives, or life stories according with what is conceived by Johnson and Golombek (2011); Fina (2010); Alsup (2006); and Signorini (2006), among others. These narratives are disseminated in the internship reports, which are setting up as a part of a semester evaluation of the professor-beginner. The reports were produced in the lapse of four semester in which participants studied the discipline called Investigation of the Pedagogical Practice and Supervised Internship in English Language $-5^{\circ}$ period, Reports I; II $6^{\circ}$ period, Reports II; III- $7^{\circ}$ periods, Reports III; and IV- $8^{\circ}$ period, and Report IV, in a total two years, from 2010 to 2011- of data collection.

\section{Identity of the Preservice Teacher}

In the text, we will pay attention to the following two participants: Laura and Richard. During the analysis, as we have perceived, this participants showed in their initial teacher-identity formation, dissatisfaction with the academic education they have received in their university course. Laura affirms in various moments, that there is a "breach" in her formation, or that her academic-theoretical formation does not prepare adequately for the real experiences in the schools yet. There is a discrepancy between the theory taught in the university on the one hand, and the experienced practice in schools on the other.

This approximation or relation between theory and practice has being discussed and analyzed by authors of the teaching and learning language area (SILVA; BARBOSA, 2009; GIMENEZ, 2009; VIEIRA-ABRAHÃO, 2002 and others). If, however, this question was rethought in the perspective of the reconstruction of professional identities, it is either "negotiating the tensions of being a student versus being a teacher" (ALSUP, 2006, p. 132). In other words, it would be a tense relationship among theories that were acquired at the university and the philosophies and expectations of the teacher in initial formation, in relation to his performance in the field-school, being this relationship experienced primarily at the borderland discourse.

It is important to mention that the negotiations between the subjectivities of the beginner-student and the trainer professor or still between the formation course received and the experiences of the field-school can provide a development of an odd professional identity, as it is conferred in the next excerpt 1 of Laura. In it, she questions that tense relationship between theory and practice, introducing in Meta Language the development of regulation of her I (JOHNSON e GOLOMBEK, 2011), when she perceives the complexity that involves the movement process from a training student to a language teacher. 
Thus, 'for us, still future teachers, there are a lot of questions, still unsolved waiting for new ideas', like she mentions in her transformer and transformative discourse:

\section{Excerpt 1}

(1) Laura: I confess that during this first internship, I had the anxiety of learning how (2) to teach English and to approach that matter so attractive for the students, which unhappily, (3) did not happen. I perceived that our theoretical discourses are not enough (4) to answer the demand of practice and still there is a breach in our (5) formation in relation to the English classes and how to teach... After (6) observing all the classes, I understood that the little acquired at the degree course is not (7) enough with the reality of everyday school...Despite of various (8) discussions witnessed at the university, I realized that the majority of disciplines applied (9) in the degree course do not show how to employ or/and modify the same (10) content in the classroom, that is to say, to the school practice... For us, still (11) future teachers, there are a lot of questions and problems that continue without (12) solutions, waiting for new ideas, new theories, new analyses, new heads (Internship Report I- emphasis mine).

The reflection and systematization (JOHNSON and GOLOMBEK, 2011) of her thoughts, as well as, the development of her professional identity about the issue of negotiation of her identities of pupil in formation/apprentice and intern teacher happened more intensively in the last semester, when she was studying the discipline called Supervised Internship IV. At that moment, she used the Report IV as a meditational and determined to reflect about her main experiences as an apprentice to analyze those experiences critically and after that, to describe those analyses to her actual conceptions about how to be an internship teacher. On that new conception of Laura can be noticed at the beginning of her writing in the Report IV when she does the following dedication using a literally fragment of the Irish author Oscar Wilde:

When we thought we were experimenting on others we were really experimenting on ourselves.

Laura perceives that during she was testing her students with her lessons plans, strategies, methods and varied approaches; she was actually, testing herself in the new identity of an intern teacher. In other words, it is put a new negotiation of academic I- apprentice- $x$ OTHER- intern teacher. It means that her professional identity was being tested by the negotiation between her subjectivities and the ones of the others involved in her formation process, such as: trained teacher, regent teacher of the field school, students of basic education, principals, coordinators, and others.

Richard is also engaged at borderland discourse through negotiations between his identity of apprentice/ academic student and researcher and as intern teacher identity, as it is noticed in the fragment below:

\section{Excerpt 2}

(1)Ricardo: The supervised internship is one of the most challenging moments during our (2) formation. (Even though I was working with the investigation through (3) Scientific Initiation (with my tutor that works with the internship), I feel too much (4) worried with the regencies and I consider them a big challenge, because I leaved from the (5) position of a student and researcher ( roles in which I do not feel any pressure) to a teacher (6) position, in which I am being tested and evaluated not only by the trained one of (7) the university, but also by the students and the pedagogical team of the school in which I am (8). (Internship Report II).

In the excerpt before, Richard, in an asymmetrical exchange of power positions (NORTON, 2000) and roles, feels tense and until abashed with the new identity he will assume: the one of preservice professor. He is aware of as a trainer teacher; he will have on difficult, conflictive, or submissive situations for being evaluated not only by the trained teacher, but also by the regent one and by the pedagogical team of the field school.

Furthermore in his narrative, Richard assumes his identity of critical-reflexive student/apprentice and even, he assumes a challenging tone that criticizes his trainer teachers for not considering the real and chaotic conditions of language teaching in public schools. Moreover, the claiming continues when he affirms that the formation he received is still traditional and based on content, and it does not match with the continuing and fast reality in which he will perform through his identity of foreign language teacher or which does not prepare him to be a foreign language teacher in this contemporary and technological reality of XXI century, like it is showed at the following excerpts:

\section{Excerpt 3}


(1)Richard: We have theorists at the university, who think about teaching from the top of their (2) formations without considering the contexts in which they are (not) going to be applied. (3)The university is too much worried with the 'how it should be' and does not create (4) purposes to 'how it is'. (Internship Report III- emphasis mine).

\section{Excerpt 4}

(5) Richard: The trainer- teachers talk that they pretend to form (6) critics and reflexive professional, but they elaborate, applied and ask for positivist and (7) excluding activities, using some materials and long term and squared methods (8) dates to form professors that would teach in the liquid future and even more (9) fast. All principles of observation, experimentation and uncovering, which are (10) characteristics of the scientific spirit, are put on favor of (11) classic readings that are incorruptible and used on dissertations and theses of guides, without having (12) space to doubt or hesitate: in a test, the subject can approve or reprove. They use (13) methods that evaluate the competency and assimilation content by the (14) student, but they have little to contribute to the performance of the classroom and it (15) seems to start to the conception that just to dominate the content, it would (16) guarantee a good class...Maybe I am arrogant, but I can wager in a (17) rate between 10 and 1 that any hyper specialist teacher could (18) be able to be better in a public school with all the (19) difficulties that we find today. They can do good as they can, but better (20) NOT. (Internship Report IV-emphasis mine).

When Richard affirms that at the university all the principles of observation, experimentation and uncovering which are characteristics of the scientific spirit, are put on favor of classic readings that are incorruptible and used on dissertations and theses of guides, or still that at the university 'we have theorists at the university, who think about teaching from the top of their formations without considering the contexts in which they are (not) going to be applied', he is unsatisfied with the formation he received in the academic space and he also claims that his trainers are in a privileged space of education, living their experiences and ideologies far from the chaotic reality of public school education.

Zeichner (1987), a theorist of matters of connection and disconnection among theories studied at the university and experienced at the field schools, suggests that the disconnected conception, expressed by Richard - between the formation he received at the university and the experiences at the field- school, happens the majority of times when the trainer is more concerned with the contents and objectives established in the disciplines programs, instead of the philosophies and beliefs generated with and inside the classroom.

When that imbalance between the practice and theory happens in the preservice teacher training, as it is observed in the excerpts of Richard, it can be for the professor in initial formation that they trainer teacher are completely unworried with the challenges that they as training students, will have to confront in public schools, let them to conclude that all the theoretical knowledge they received at the university is not important for their future professions.

However, Richard shows a professional, confident and a develop identity, to the point of being in a symmetric position of its trainers when he provokes them to manage a class better than him: 'but I can wager in a rate between 10 and 1 that any hyper specialist teacher could be able to be better in a public school with all the difficulties that we find today'. As this already called attention, it matters to make clear that is justly in that initiating period of scholar activities, challenging to the novice professor, that his/her professional identity starts to be outlined and gain forms.

Many teachers do not achieve to negotiate this reconstruction of their personal and professional identities, from which can result in negative consequences for the future professional training, or even, the termination of the profession they have chosen with their ideologies, abilities and competencies, which they have thought to be the most compatible. This happened with Ricardo, who was worried about his appearance as an adolescent, due to the fact that he is physically short, compared with the Brazilian male average. The result is the following concern:

\section{Excerpt 5}

(1)Ricardo: Initially, I let my goatee grown, with the (2) expectation to look older and maybe guarantee a little more (3) respect, but when I met the class, most students had more (4) beard than I. Yes, it's funny, but it's true. (Internship Report II- emphasis mine). 
Nevertheless, Ricardo reflects systematically with his participation in $\mathrm{CdP}$, about his identity negotiations through the borderline discourse (ALSUP, 2006), between the Self-Personal and the Self-Professional. This motivated him to pass from an intern-teacher to a professor of languages, to "interfere in the best possible way". Now, we are going to focus on another identity facet: the identity of a language professor.

\section{Identity of a Language Professor}

Laura at her identity of a language professor assumes the responsibility of theorizing her own teaching method. She looks to check forms to her own pedagogy (ALSUP; 2006) through a critical reflexion about several methods and approaches of language teaching, without waiting a ready recipe from her internship supervisor. Moreover, she demonstrates the development of her professional identity and recognizes the significant relevance of old theories that at ingenious moments, the professor thinks of substituting using newer methods and approaches, looking for 'innovations' without perceiving that for a real innovations of her/his attitudes happens in relation to teaching, some changes have to occur at herself/himself, at her/his identities subjectivities as the participant demonstrates in the excerpt below:

\section{Excerpt 6}

(1)Laura: As teachers, we must not be extremists considering that it (2) is necessary to mix the innovation with what is traditional. Now that we are conscious of those (3) and other aspects, we must look for some alternatives of language teaching that (4) escape from a mere reproduction of methods without excluding the pattern of teaching, but do not (5) let them be exclusive. (Internship Report II).

(6)Laura: In that way, the teacher is obliged to be adapted with the reality of the classroom, (7) leaving aside all those beliefs of how being a good professor to (8) attend the students' demands (Internship Report III).

In the fragments from the Internship Report II and III of Laura, she concludes that the teacher must think primarily of his/her students' interests and not exclusively of himself/herself and the achievements as a professional modifying, in that way, the conception of being a good teacher. Consequently, she also shows some changes of her professional identity after introducing moments of borderland discourse and the negotiation of her personal identity -in which she had beliefs about how 'to be a good teacher'. She stopped it this to assume a new professor identity, that is to say, she perceives that not only by her interests must dominate the classroom, but also her students over all.

Lastly, the participant already expresses, in a firm way, to be a foreign language teacher- teacher identity- and no more an intern-teacher -preservice teacher identity-. So, she defines her conception of being a foreign language teacher, pointing out it worth it to struggle, like on the prior discourse -of other regent teachers- she expressed at the internship II, even though it is frustrating or discouraging. So, let's look at the fragment and discuss in detail its implications for the reconstruction of Laura's identity:

\section{Excerpt 7}

(1)Laura: At the end of the Internship we understand, taking into account the acquired experience in (2) our regency practice, that being a foreign language teacher or of any (3) other subject it is to know how to be adapted to different situations and have a plan (4) B to dribble the unexpected situations that happen at the moment of (5) 'let's see'. Being a teacher is to have passion for what it is made and believing in education, (6) even though everybody says that it is not worth it. (Internship Report III-emphasis mine).

(7) Laura: The teacher is the most important figure of the classroom and he/she seriously needs to carry (8) that responsibility, assuming that because when he/she is there is the person who (9) directs there. Even though, the system sometimes dictates the rules and imposes the (10) practices, it is up of him/her to reformulate and adapt the (11) classes, taking into account the context of every classroom and the (12) students' diversity. (Internship Report III- emphasis mine). 
(13) Laura: What we have now is the worry of our challenge: To be a different (14) teacher in front of the diversities we will have (15) ahead of our students, remembering the promise (16) that we made of being different of the ones that we criticized and are (17) responsible, in a way, of flying until our 'ivory tower' (Internship Report IV-emphasis mine).

The three narrative segments of Laura reveal that the participant has a flexible professional identity, that is open to changes and adaptations in front of other challenges or negotiations that she will have to do with her self-personal and her selfprofessional. It can be observed at the discourse of the first narrative segment, when she affirms that being a teacher is 'to know how to be adapted to the different situations and have a plan B to know to dribble with unexpected situations'. It is also, in the second narrative discourse her flexibility when she says: 'It is up to that teacher [my professional identity] to reformulate the proposal [of the OTHER represented here by the voices of governors, principals, coordinators, professors, students and other actors] to adapt the classes'. That flexibility influences in the third segment, as we can observe, it is a fragment taken from the Internship Report IV, and she retakes that same professional identity face at the following semester when she affirms again: 'What we have now is the worry of our challenge: To be a different teacher' - [l-a foreign language teacher different from the OTHER, the regent teacher of the field-schools, the trainer professor, the I intern professor, the I- student/apprentice and others] -

Richard also presents a professor identity too much holistic and developed. It can be perceived when it is put in front of the social OTHER and when he confesses his subjectivities changes or even, when he contrasts one change of his I versus the social OTHER. That is represented here by the politicians and governors, who are responsible by the laws that regularize the Brazilian Education, the educational system, as well as the principals, coordinators, secretaries, students, and teachers. That means: the social community involved on the educational process. Look at the following:

\section{Excerpt 8}

(1)Richard: The contact with the education by the perspective of the teacher alters, (2) profoundly, the way we feel and perceive the society and it interferes in a decisive (3) manner at the social processes in which we are involved...I believe that I (4) can construct such critics to experience what I defend and I am aware that (5) even I can achieve my own objectives. For that reason, I do not pretend to desist of (6) progressing and helping to make the positive difference in every classroom (Internship Report IV- emphasis mine).

It is necessary to point out the development of the professional identity when he shows us that he is aware of his professional identity 'will become' eternal, (re) doing at future negotiations of his SELF-personal versus SELF-professional, when he says: 'I am aware that I can achieve it'. According to Moita Lopes and Bastos (2002, p.9), that 'becomes' is a project of life in which we engage and it moves the subject 'to ambition to reflect about a social life', try to comprehend it at the same time in which "it points out new configurations about who we are or who we can be" (MOITA LOPES e BASTOS, 2002, p 9).

In Moodle, Ricardo echoes in his discourse a paternalistic language teacher's identity and was concerned about his relationship with the students, which is indicated by the use of the two verbs: attend and watch over. In this way, Ricardo calls in himself the responsibility to act like parents who take care for the education of their children's, as can be seen in the excerpt below:

\section{Excerpt 9}

(1)Richard: Don't come to tell me that if a teacher explains how a (cult) variety of (2) grammar of determined language (English, for (3) example) behaviors in determined situations to teach a language, but it is (4) not like that. You can be teaching something, except the language: the language cannot (5) be learned, it is lived. For me, the professor must incentive the student to live the foreign (6) language, attending it what he demands (like (7) parents) and watching over for this experience happens in a more salutary (8) possible way.

\section{(9)What is your concept of teaching? (CdP-Saturday, October, 23', 2010$)$.}

Also, Laura presents an identity of a language teacher too much developed and critical (FAIRCLOUGH, 2003) when she lets to echo her power awareness at her discourse in Moodle. She believes in the professor as a more important figure in the classroom: 'When you are there, you are the person who directs there!' and also by 'the budget' (NORTON, 2000) in her profession as an objective of improving the practice each day. In a similar way, she presents an active and conscious professional identity of her transformer role inside that social context, given that she thinks, at her professional context, that 
she is not happy with the conditions that are imposed. In other words, a professional engaged with the aspects and social actions of her environment, according to what is expressed next:

\section{Excerpt 10}

Laura: The professor is the most important figure in the classroom and he/she needs (2) to assume that, because $i W h e n$ you are there, you are the person who directs! And don't come to (3) tell me that the system is the one that dictates your class, because it is not like that. The teacher is the (4) figure more influent in the classroom, and for that reason, it is necessary that assumes his/her (5) position, showing to the student the relevance of the content he/she is teaching. It is (7) just at that moment when he/she can present the foreign language through a vision (8) that is it beyond from the linguistics aspects, giving inside of political and (9) cultural questions. In that way, I believe that being a teacher is a professional (10) that is not happy with the conditions that are imposed to work, and does not have limits to complain, but also look for the perfection and the (12) reflection in order to improve her/his practice each day. "What does mean to be a (13) foreign language teacher? (CdP-Monday, June, $20^{\text {th }}$, 2011- emphases mine).

Richard continues to express his rejection for being an English language teacher, mirroring himself in the reflex of rejecting English language as the 'other' colonizer, imperialist, and arrogant in a superior relationship and power of I-speaker of the mother tongue, as it is evidenced in the other excerpts of Richard in which he shows that rejection. Sequentially, he believes that he does not have the 'don' or 'vocation' to be an English language teacher and concludes 'that it is not what he desires'.

\section{Some Considerations}

To conclude, I would like to come up four inferences which seemed relevant for the analysis and the discussion of the presented data. First: The participants of the institution that was the context of the research, confronted a long period of change that made the contexts analyzed privileged arenas for the negotiation of new professional identities, which made it palpable to verify the (re)construction of the professional identity of both participants. The participant who engaged more in the borderline discourse was Ricardo, despite finishing his course refusing to be a foreign languages teacher, and he developed his professional identity significantly, identifying himself as a teacher of mother language.

Second: To focus the reconstruction of a professional teacher identity in initial formation in some virtual and presence contexts in a Letras Course, we perceive the transiency of the categorized identities such as: 1) student/apprentice identity; 2) the identity of the internship professor; 3) the identity of a foreign language teacher; and 4) the socio-cultural identity. It is important to emphasize that they do not obey to a chronological order of development and interaction represented properly in this study, as a progressive movement of back- and- forth pendulum.

Third: All the discussions presented before about the excerpt of Laura and Richard reinforce our belief of the importance of the discipline Supervised Internship II, in other ways, the knowledge of theoretical and practices for the reconstruction of the professional identity of these teacher/apprentices, as well as for the consciousness of them in relation to the motivation role and the budget in the cultural-capital, that means, the improvement of their future professional career or in a better future (NORTON, 2000; BOURDIEU, 1997, 1991).

Lastly, the fourth: To analyze the interactions of the two participant in Moodle Platform, we observe there the most concurrency in the construction of the professional identity, which indicates that it space is preferentially like a environment of sharing frustrations, emotions, achievements, passions, anxieties, wishes, etc. We understand that this sharing of experiences served as emotional scaffolds (ROSIEK, 2003). Finally, it is evident that the narratives or stories when told in both virtual and/or presence contexts, would be a privileged site to understand synchronically the role of a language in the construction of who we are.

\section{Bibliography}

[1] ALMEIDA FILHO, J. C. P. Dimensões comunicativas no ensino de línguas. 3. ed. Campinas-SP: Pontes, 2002.

[2] ALSUP, J. Teacher Identity Discourses: Negotiating Personal and Professional Spaces. Mahwah, New Jersey: Lawrence Erlbaum Associates, 2006.

[3] BARBOSA, S. M. A. D. Escrita em ambiente virtual na formação inicial do professor de língua estrangeira. In: SILVA, W. R. (Org.). Letramento do Professor em Formação Inicial: Interdisciplinaridade no Estágio Supervisionado da Licenciatura. Campinas: Pontes, 2012. p. 165-80. 
[4] BARCELOS, A. M. F. Narrativas, crenças e experiências de aprender inglês. Linguagem \& Ensino (UCPel), v. 9, p. 145-75, 2006.

[5] BOURDIEU, P. ; PASSERON, J. C. Reproduction in education, society, and culture. London: Sage. 1990.

[6] Language and Symbolic Power. Edition and introduction of THOMPSON, J. B. Translation of RAYMOND, G. and ADAMSON, M. Cambridge: Polity Press, 1991.

[7] CELANI, M. A. A.; COLLINS, H. Formação contínua de professores em contexto presencial e a distância: respondendo aos desafios. In: BARBARA, L.; RAMOS, R.C. G. (Orgs.). Reflexão e ações no ensinoaprendizagem de línguas. Campinas. Mercado de Letras, 2003, p.125-32.

[8] Linguística aplicada, contemporaneidade e formação de professores. Investigações (Recife), Recife, PE, v. 17, n.2, p.79-96, 2004.

[9] CLARKE, M. Language Teacher Identities: co-constructing Discourse and Community. Clevedon: Multilingual Matters, 2008.

[10] COELHO, H. S. H. Experiências, emoções e transformações na educação continuada. 2011. Tese (Doutorado em Estudos Linguísticos) - Faculdade de Letras, Universidade Federal de Minas Gerais, Belo Horizonte, 2011.

[11] CORACINI, M. J. R. F. Língua estrangeira e língua materna: uma questão de sujeito e identidade. In: CORACINI, M. J. R. F. (Org.). Identidade e discurso: (des)construindo subjetividades. Campinas: Unicamp, 2003. p. 139-59.

[12] DUFF, P.; UCHIDA, Y. The negotiation of teachers' sociocultural identities

[13] and practices in postsecondary EFL classrooms. TESOL Quarterly, vol. 31, p. 451-86, 1997.

[14] FAIRCLOUGH, N. Language and power. London: Longman. 1989.

[15] FETTERMAN, D. M. Etnography: step by step. London: Sage Publications, 1998.

[16] FIGUEIREDO, C. J. Construindo Pontes: a produção oral dialógica dos participantes do processo ensinoaprendizagem de inglês como língua-cultura estrangeira. 2007. Tese (Doutorado em Letras: Estudos Linguísticos) - Universidade Federal de Goiás, Goiânia, 2007.

[17] FINA, A. Tempo, espaço e identidade em narrativas de imigração. In: MOITA LOPES, L. P. ; BASTOS, L. C. (Orgs.) Para além da identidade: fluxos, movimentos e trânsitos. Belo Horizonte: UFMG. p. 85-106, 2010.

[18] FREEMAN, D.; JOHNSON, K. E. Reconceptualizing the Knowledge-base of language teacher education. TESOL Quartely, vol. 32, p. 397-417, 1998.

[19] GRANT, C. A.; ZEICHNER, K. M. Inservice Support for first-year Teachers: The State of The Scene. In: Journal of Research and Development in Education. Vol.1, p. 99-111, 1981.

[20] GIROUX, H. A. Teachers as Intellectuals: Toward a critical pedagogy of learning. Granby, MA: Bergin \& Garvey, 1988.

[21] _ Cruzando as Fronteiras do Discurso Educacional: Novas Políticas em educação. Porto Alegre: Artes Médicas, 1999

[22] GRIGOLETTO, M. Representação, identidade e aprendizagem de língua estrangeira. In: CORACINI, M. J. (Org.). Identidade e discurso: (des)construindo subjetividades. Campinas: Unicamp, 2003. p. 223-35.

[23] JOHNSON, K. E. Second Language Teacher Education: a sociocultural perspective. New York: Routledge, 2009.

[24] _ ; GOLOMBEK. P. R, The Transformative Power of Narrative in Second Language Teacher Education. TESOL Quarterly, vol. 40, p. 1-22, 2011.

[25] MAHER, T. M. Sendo índio em português. In: SIGNORINI, I. (Org.). Lingua(gem) e identidade: elementos para uma discussão no campo aplicado. Campinas-SP: Mercado de Letras, 2002, p. 115-38.

[26] Formação de Professores Indígenas: uma discussão introdutória. In: L. D. B. GRUPIONI. (Org.). Formação de Professores Indígenas: repensando trajetórias. Brasília: MEC/SECAD, 2006, v.3, p. 11-38.

[27] MOITA LOPES, L. P. Discursos de identidade em sala de aula de leitura de L1: a construção da diferença. In: SIGNORINI, I. (Org.). Lingua(gem) e identidade: elementos para uma discussão no campo aplicado. CampinasSP: Mercado de Letras, 2002a.

[28] Identidades fragmentadas. Campinas, SP: Mercado de Letras, 2002b.

[29] MOITA LOPES, L. P.; BASTOS, L. C. Identidades: recortes multi e interdisciplinares. Campinas-SP: Mercado de Letras, 2002c.

[30] MORGAN, B. Identity and intonation: Linking dynamic processes in the ESL classroom. TESOL Quarterly, vol. 31, n. 3, 431-50, 2004. 
[31] NORTON, B. Identity and Language learning: Gender, ethnicity and educational change. Edinburgh: Pearson Education, 2000.

[32] . Towards a model of critical language teacher education. In: Language issues, vol. 17, p. 12-17, 2005.

[33] ROSIEK, J. Emotional scaffolding: An exploration of teacher knowledge at the intersection of student emotion and subject matter content. The Journal of Teacher Education, vol. 54, n. 5, p. 399-412, 2003.

[34] ROGERS, D. L.; BABINSKI, L. M. From Isolation to Conversation: Supporting new teachers' development. Albany: State University of New York Press, 2002.

[35] SILVA, W. R.; BARBOSA, S. M. A. D. Desafios do Estágio Supervisionado numa licenciatura dupla: flagrando demandas e conflitos. In: GONÇALVES, A. V. et. al. (Org.). Estágio Supervisionado e Práticas Educativas: Diálogos Interdisciplinares. Dourados: UEMS, 2011. p. 181-206.

[36] VARGHESE, et al. Theorizing language teacher identity: Three perspectives and beyond. Journal of Language, Identity, and Education, vol.6, n. 4, p. 21-44, 2005.

[37] VIEIRA-ABRAHÃO, M. H. A prática de ensino e o estágio supervisionado como foco de pesquisa na formação do professor de língua estrangeira. Revista Contexturas, vol.1, p.49-54, 1992.

[38] Conflitos e incertezas do professor de língua estrangeira na renovação de sua prática de sala de aula. 1996.Tese (Doutorado em Linguística Aplicada) - Instituto de Estudos da Linguagem, Universidade Estadual de Campinas, Campinas-SP: 1996.

[39] WENGER, E. Communities of Practice: Learning, Meaning, and Identity. Cambridge: Cambridge University Press, 1998.

[40] ZEICHNER, K. M. The ecology of Field experience: Toward an understanding of the role of Field experiences in teacher development. In: HABERMAN, M. ; BACKUS, J. (Eds.). Advances in Teacher Education. Vol. 3. Westport, CT: Greenwood, 1987. p. 94-114. 